\title{
For the Love of Prophet Muhammad
}

\author{
Religious Devotion and Political Mobilisation among the Barehis \\ of Pakistan
}

Alix Philippon

This chapter is based on fieldwork undertaken in Pakistan, during which interviews were conducted, observations noted, and religious literature and journalistic articles collected. I intend to show that, in this country created in the name of Islam, the figure of Prophet Muhammad has proved efficient in structuring social issues, offering a repertoire to articulate political claims and mobilise for collective action. The Prophet could thus be apprehended as a "symbol" that does not possess a single meaning only, but allows for competing interpretations. ${ }^{1}$ The Prophet could also be viewed as an "empty signifier", that is efficient in mobilising powerful emotional projections and is left open and ambiguous in its references, thus gaining a mobilising quality. Generally speaking, the Prophet has been a component of identity politics, used by religious groups and individuals to negotiate and articulate their identity. He has also been used as a political resource and instrumentalised as a legitimising tool by both state and non-state actors. I will explore these issues through the lens of the Barelwi movement that has the most loudly claimed its love for the Prophet and defended his honour against any attacks. "We can tolerate anything, but we won't tolerate anything said against the Prophet, peace be upon him," is indeed one of the slogans making the rounds among the Barelwi activists mobilised around the blasphemy issue within the new party Tehreek-e Labbaik Pakistan (TLP) led by the religious scholar Khadim Hussain Rizvi. ${ }^{3}$

Mostly overlooked by scholars, the Barelwi theological school was founded in the nineteenth century in India by the Sufi and 'älim Ahmed Reza Khan Barelwi (1856-1921). It is often presented as a form of traditionalist reaction to more reformist movements, namely, the Deobandi and Ahl-e Hadith, critical of some aspects of Sufism. The Barelwis call themselves Ahl-e Sunnat wa-lJama'at (the people of the tradition and of the community of the Prophet). This

1 Braud, L'émotion en politique.

2 Laclau, On Populist Reason, 232.

3 Kalbe, "Who Is Khadim Hussain Rizvi?"

(C) ALIX PHILIPPON, 2022 | DOI:10.1163/9789004466753_017

This is an open access chapter distributed under the terms of the CC BY-NC-ND 4.9licenser 
expression both emphasises the centrality of the Prophet's tradition (sunna) in their practices and belief system, and the commitment to the religious majority. It is used by Barelwis to designate those adhering to the religious interpretation of the founder of the movement. But as Usha Sanyal has rightly pointed out, this expression also highlights a "universalist claim linking its pretenders to the Sunni world beyond the subcontinent", 4 and a way of denying this link to other Muslims who do not respect the norms of Ahmed Reza. In the framework of Pakistan, the Barelwis generally believe they represent the majority of the population in terms of religious sensibility and as such claim a more prominent position than they have had in both the religious and political fields.

The actors of the Barelwi movement authoritatively appropriate the figure of the Prophet as the main identity symbol and supreme religious authority after God. For Ahmed Reza and his devotees, the Prophet is the first and foremost creation of the universe, the primordial entity possessing superhuman qualities: he is omniscient and has the knowledge of the invisible ('ilm-e ghaib); he is omnipresent, composed of a special light (nur-e muhammadi), and is also an intercessor with God. Thus, Barelwis are extremely protective of the Prophet, to whom they attribute numerous miracles that are often recalled during the massive celebrations organised to commemorate his birth (mehfil-e milad). Such beliefs pertain to polytheism (shirk) in the eyes of more reformist actors. The debates revolving around the Prophet and the saints have thus been at the basis of the most widespread religious conflict in Pakistan ${ }^{5}$ and have fuelled sectarianism. ${ }^{6}$ The identification of the enemies of a movement is a key procedure in defining its identity and establishing the us/them frontier. In the Barelwi perspective, all the groups perceived as "Wahhābīs" such as the Deobandis and Ahl-e Hadith are excluded from Sunnism. ${ }^{7}$

Barelwis identify themselves as the true "lovers of the Prophet", a quality that they deny to other sects. For Ahmed Reza, the Prophet was so close to God that he had almost replaced the latter as the object of devotion, ${ }^{8}$ and passionate love ( $i s h q$ ) for him became the true centre of Barelwi faith. " "Not making this love your centre is to be lost. When you love the Prophet, and you follow his life, then your heart, your eyes, and your work will be directed towards the

4 Sanyal, Devotional Islam, 166.

5 Sherani, "Ulema and Pir in the Politics of Pakistan", 217.

6 The term sectarianism designates confrontational or even violent interactions between different Islamic groups. The confrontations can involve Shīīs and Sunnīs, but can also oppose Sunnī groups to each other.

7 Sanyal, Devotional Islam, 247.

8 Sanyal, Devotional Islam, 164.

9 Ahmed, Nida-e Ahl-e Sunnat, 29. 
good."10 In the symbolic universe of the Barelwis, the love for the Prophet is the one stage that leads to the perfect love of God. Practically, it means to scrupulously imitate the life of the Prophet in all domains. In this perspective, living according to the tradition of the Prophet and respecting him bestow spiritual benefits (including baraka) upon the believer.1 Love for the Prophet, as the main emotion claimed by the community, could be analysed as an emotional habitus, that is to say, the embodied emotional disposition of a group that is both internalised and enacted through religious training, rituals and literature, social dramas, and emotional repertoires of action. Indeed, the Barelwi movement has succeeded in mobilising religious values and representations centred around the Prophet that have contributed to the construction of a community on the basis of a widely shared minimal code.

After exploring the multiple mobilisations of the Barelwi movement in favour of the Prophet throughout the history of Pakistan, we will in a second part more specifically focus on one Barelwi moral entrepreneur of mobilisation, the scholar and Sufi Pir Afzal Qadri who, after a long career devoted to the Prophet, has recently become one of the leaders of the new TLP party. We will eventually try to analyse the mobilisation of this party that has successfully organised Barelwi support and rank and file around the issue of blasphemy.

\subsection{The Prophet Muhammad at the Heart of the Barelwi Mobilisations}

According to Mary Bernstein, "identity" can be much more than just a resource used by a group to sacralise itself in the confrontation with "the other". It can also be a strategic tool both for the legitimisation of a stigmatised group or for collective action. ${ }^{12}$ And the notion of "repertoire of collective action" coined by Charles Tilly can be useful to understand what genres and registers the mobilised groups are going to use to institutionalise their action, express their claims, and celebrate their identity. ${ }^{13}$ Indeed, a tactical repertoire can be used to construct a collective consciousness and identity, thus performing a function that is internal to the group itself, while succeeding in communicating with external targets. ${ }^{14}$ Therefore the repertoire can also be the locus of the negotiation of the border between the group and its opponents.

\footnotetext{
10 Ahmed, Nida-e Ahl-e Sunnat, 29.

11 Ahmed, Nida-e Ahl-e Sunnat, 38.

12 Bernstein, "Celebration and Suppression".

13 Tilly, La France conteste de 1600 à nos jours.

14 Della Porta and Diani, Social Movements.
} 
The veneration of the Prophet has notably inspired emotional repertoires of mobilisation, such as the celebration of his birthday (milad-un nabi), or the defence of his honour. The latter provide the Barelwis with the means to assert their identity, all the more that the first one is considered to be an innovation by "Wahhābī" groups. Generally speaking, big gatherings or yearly congregations organised by religio-political groups fulfil multiple functions, starting with that of indicating the size and logistic base of each group. They offer to the participants the opportunity to create and strengthen social and solidarity ties. ${ }^{15}$ These congregations are used as ideal platforms wherefrom they broadcast their political programmes or strategies and religious messages. A connection between the group's prestige and that of the Prophet, a bond of honour so to speak, can be established. These gatherings also embody the notion of the umma as numerous participants from other Muslim countries can take part in the celebrations. ${ }^{16}$ Besides, the month of the birthday of the Prophet (Rabi-ul Awwal) is marked by multiple spiritual conferences or congregations (mehfil-e milad) organised in honour of the Prophet. They often mobilise hundreds of thousands of people during processions that occupy public space. And in the framework of sectarianism plaguing Pakistan, it has taken on a symbolic and political dimension. As a symbol of the love for the Prophet, thus as a symbol of the whole community that is calling on this passionate love, the milad aims at strengthening the feeling of belonging to the Ahl-e Sunnat community and to reassert this identity by staging a repertoire of action that is highly controversial in the public arena. Thus, this repertoire of action has widely contributed to the "symbolic construction of the community".17

Numerous causes revolving around the Prophet have triggered protests that have gradually become politicised. Throughout the history of Pakistan, many Islamic movements or parties have mobilised in favour of these causes, and sometimes competed about them, but the Barelwis have often organised and taken the lead of these collective actions in order to defend their role model. Created in 1948 immediately after partition to protect and promote Barelwi doctrine and institutions and take part in the political process, the Jamiat-e 'Ulama-e Pakistan (JUP) has remained the Barelwi actor of reference until the 1980 os and has gradually asserted itself inside the Islamist field. If Barelwis are usually perceived as more "tolerant" than other religious trends, their expression within the JUP displays a very orthodox and rigorist religious ideology, as well as a political one that is very similar to other Islamist parties. At the same

15 Shafqat, "From Official Islam to Islamism", 131.

16 Shafqat, "From Official Islam to Islamism", 132.

17 Cohen, The Symbolic Construction of Community. 
time, it is linked to Sufi orders and their leaders, who fill the ranks of the party leadership. The JUP has succeeded in using its rituals and worldview to address the masses and gain political and religious supporters. ${ }^{18}$

Firstly, Barelwis have mobilised alongside other Islamist groups for the protection of the seal of prophecy (khatam-e nabuwwat). In 1953, the Jama'at-e Islami (JI), the Deobandi Jamiat-e 'Ulama-e Islam (JUI), and the JUP led the first anti-Ahmadiyya movement of Pakistan. The founder of this reformist sect, Ghulām Ahmad, had declared in 1889 that he was the Messiah, the Mahdī, and the "appearance" (burūz) of the Prophet Muhammad. ${ }^{19}$ This last ambiguous claim is often interpreted by critics of the Ahmadiyya as "reincarnation", and as an unforgivable breach of the finality of Muhammad's prophecy. Furthermore, some Aḥmadīs talk about Ghulām Aḥmad by using the same Arab terms of rasūl (messenger) and nabì (prophet) that in Islam are reserved for Muhammad. ${ }^{20}$ Ghulām Aḥmad and his followers are thus considered as apostates by mainstream Sunnī Muslims. All religious groups demanded that their community be declared non-Muslim and that their members be removed from important administrative and political positions. The presence of Ahmadīs within the power structure, such as Sir Muhammad Zafrullah Khan, the foreign minister at that time, ${ }^{21}$ was considered as "dangerous to Islamic interests" by the 'ulam $\vec{a} .{ }^{22}$ The then president of the Barelwi JUP, Maulana Abul Hasanat Qadiri, became the president of the consultative assembly of the newly created Tahaffuz-e Khatam-e Nubuwwat Tehreek (Movement for the Protection of the Finality of Prophecy).

In 1974, the issue resurfaced in a virulent countrywide movement led by eight Islamic parties demanding the excommunication of the Ahmadiyya. This new mobilisation for the protection of the finality of prophecy was partly justified by the definition of "Muslim" introduced in the 1973 constitution. The latter is often attributed to the Barelwi leader Shah Ahmed Nurani who tried to limit the political ambitions of the Ahmadīs, ${ }^{23}$ for only Muslims could become president or prime minister of Pakistan. Indeed, as written in the 1973 constitution of Pakistan, 'Muslim' means a person who believes in the unity and oneness of Almighty Allah, in the absolute and unqualified finality of the Prophecy of Muhammad (peace be upon him), the last of the Prophets and does not believe in, or recognise as a prophet or religious reformer, any

\footnotetext{
18 Malik, "The Luminous Nurani", 43.

19 Friedmann, Prophecy Continuous; Sèze, "L'Ahmadiyya en France", 5.

20 Friedmann, Prophecy Continuous; Sèze, "L'Ahmadiyya en France", 5.

21 Zaman, Islam in Pakistan, 170.

22 Shah, Religion and Politics, 5 o.

23 Nurani was the leader of the JUP from 1973 up to his death in 2003.
} 
person who claimed or claims to be a prophet, in any sense of the word or of any description whatsoever, after Muhammad (peace be upon him)."24 Prime Minister Zulfiqar Ali Bhutto eventually gave in to the Islamists' demands. An amendment to the constitution was unanimously voted in the National Assembly that declared the Ahmadīs to be "non-Muslims".

The concept of nizam-e mustafa, the system of the Prophet, is also central in the political thought of Barelwis. This system works as a mythical order originating in the golden age of the beginning of Islam, and it includes more than just worship: it shows the necessity to politicise Islam within the community of believers. ${ }^{25}$ According to Shah Ahmed Nurani, the nizam-e mustafa can solve all the problems of the country and is nothing less than the "destiny" of Pakistan that can prevent secularism from putting down roots. ${ }^{26}$ It is associated with the idea of equality for all in terms of rights, job, health, or even education, but also with the idea of justice. ${ }^{27}$ An ideal Islamic welfare state is what is supposed to take shape under the banner of that nizam-e mustafa. In the preamble to the JUP constitution, it is one of the two targets of the party, along with the protection of the seal of prophecy. Both are supposed to bring happiness and prosperity to Pakistan. It even gave its name to a massive mobilisation against Bhutto in the 1970s. After he scheduled anticipated elections for March 1977, nine parties who were sitting in the opposition benches formed the Pakistan National Alliance (PNA) mostly led by the three main Islamic parties (JI, JUI, JUP). ${ }^{28}$ The PNA programme called for the establishment of the nizam-e mustafa. After Bhutto's party won 155 seats, the PNA, which only got 36 votes, decided to reject the election results on the basis of malpractice. The PNA launched a movement of civilian disobedience throughout the country called Tehreek-e Nizam-e Mustafa. It soon turned into a popular Islamic cause in which the JUP played an important role. Bhutto's policies had led to a general discontent amongst the population. The PNA succeeded in channelling the anger into a credible movement notably thanks to a slogan of devotion to the Prophet that triggered the enthusiasm of the masses. ${ }^{29}$ Bhutto eventually gave in to the Islamists' demands and started Islamising Pakistani society by banning alcohol, nightclubs, and gambling, before declaring Friday as a weekly holiday (instead of Sunday). He also nominated Zia al-Haqq as chief of army staff. The latter staged a coup, imprisoned Bhutto, and had him sentenced to

24 Constitution of the Islamic Republic of Pakistan (1973), "Chapter 5 - Interpretation", Accessed 26 September 2021, http://www.commonlii.org/pk/legis/const/1973/13.html\#c5.

25 Interview with Qari Bahadur Zawar, general secretary of the JUP, Lahore, April 2007.

26 Nida-e Ahl-e Sunnat, February 2002, 42.

27 Constitution of the JUP, 37.

28 Ahmad, Jam'iyyat Ulama-i-Pakistan, 214-15.

29 Shah, Religion and Politics, 229. 
death and executed. Thus, the nizam-e mustafa movement eventually led to Bhutto's downfall.

The "preservation of the honour of the prophetic message" (tahaffuz-e namoos-e risalat) is one of the main causes of the Barelwi movement and a tool of legitimisation against Deobandis. ${ }^{30}$ An association was created with this name in 1988 by a Barelwi 'âlim to lead the protest against the publication of the (in)famous Satanic Verses written by Salman Rushdie. From the Barelwi point of view: "Whereas Barelwis have issued numerous fatwas, Deobandis have remained silent."31 Even worse than silence, they have supposedly supported the publication of the book in India in the name of freedom of expression. For Barelwis, whose hearts have been "broken" by that incident, it is a perfect example of the fact Deobandis “don't have love in their heart for the Prophet". 32 "We are not trying to attract attention, we just want to explain people who are the offenders. It is just tahaffuz-e namoos-e risalat." ${ }^{33}$ Thus, one of the main arguments mobilised by Barelwis against Deobandis is that they "insult the Prophet". It is indeed a recurrent criticism in the Barelwi polemical literature. As they claim to be the "true lovers" of the Prophet, Barelwis feel that whoever insults him also insults them and, conversely, whoever insults them insults him.

As for the issue of blasphemy against the Prophet, the Barelwi groups have all aligned on the Pakistani penal code that was amended in the 1980s under Zia al-Haqq. Article 295c, pertaining to the use of derogatory remarks in respect of the Holy Prophet, and introduced in 1986, states that "Whoever by words, either spoken or written, or by visible representation or by any imputation, innuendo, or insinuation, directly or indirectly, defiles the sacred name of the Holy Prophet Muhammad (peace be upon him) shall be punished with death, or imprisonment for life, and shall also be liable to fine." As analysed by Amélie Blom, this article "dramatically shifted the institutionalised 'rules of emotions' by authorizing the state to kill its 'unauthentic' subject in wider and even more ambiguous situations". ${ }^{4}$ Thirty years later, in 2016, the Barelwi Tehreek-e Labbaik will successfully claim that right to kill.

In 1995, during a conference in Lahore of the tahaffuz-e namoos-e risalat, numerous Barelwi pirs and 'ulamä' issued a fatwa stating that the punishment for insulting the Prophet Muhammad is the death penalty. For them, whoever

\footnotetext{
3o Nāmūs can also be translated as "reputation", "prestige", or "dignity".

31 Zadiri, Da'wat-e Inșā f, 5 .

32 Zadiri, Da'wat-e Inșāf, 5 .

33 Zadiri, Dawat-e Inșāf, 5 .

34 Blom, “The 2006 Anti-'Danish Cartoons' Riot in Lahore”, 84.
} 
does not protest against blasphemy "does not belong to their community". This is a clear reminder that the boundaries of the Ahl-e Sunnat's identity are drawn with the love for the Prophet - and hence the hatred for the blasphemer. The latter is considered as an apostate and his or her repentance will not be accepted. ${ }^{35}$ Hence, "emotions appear to be the mediations through which social integration takes place,"36 whether it is love or hate. In 2000, when General Pervez Musharraf tried to amend the blasphemy law and proposed a change in the procedure for the registration of trials, the pressure of the Islamists forced him to back-pedal. The tehreek-e tahaffuz-e namoos-e risalat was thus revived in reaction to Musharraf's intention. During the demonstrations against the Danish caricatures on 14 February 2006 in Lahore, riots erupted that caused massive disruption and destruction. It was the Barelwi mufti Sarfraz Naeemi who partly organised the demonstration. He was arrested for the violence outbreak and booked on charges of terrorism after three weeks on the run. As analysed by Blom:

Social protests, and even riots, are events which institute a public arena: actors accomplish symbolic performances, enact emotions, claim moral preferences, reaffirm collective identities, and dramatize conflicts between distinct social groups.... This is particularly worth studying in the Pakistani context wherein the public expression of emotions has become, with time, a matter of harsh controversies and the language in which the boundaries between rival sects are commonly drawn. ${ }^{37}$

In March 2006, a Barelwi congregation reasserted in Karachi that a blasphemer deserved death and signed a fatwa on this specific topic written by Pir Afzal Qadri. ${ }^{38}$ Barelwi activists distributed pamphlets against the Danish government, calling for a boycott of Danish products, and denouncing the "terrorism" of the caricaturists. This is one of the most prominent Barelwi leaders and arguably one of the most active ' ulam $\bar{a}$ ' as far as mobilising for the sake of Prophet is concerned. The study of Qadri's biography (or even hagiography) and his individual career will give us invaluable insights into the emotional culture and habitus of a prominent Barelwi leader whose life and work have been almost entirely devoted to the Prophet of Islam. ${ }^{39}$

35 Nida-e Ahl-e Sunnat, April 1995, 38.

36 Hervieu-Léger and Azria, eds, Dictionnaire des faits religieux, 314.

37 Blom, "The 2006 Anti-'Danish Cartoons' Riot in Lahore", 95.

38 Daily Times, "Barelvi Scholars Want Death for Blasphemers".

39 This document (with no title nor specific date of publication) was given to me by Pir Afzal Qadri when I visited him at his home in Gujrat in May 2009. 


\subsection{The Barelwi Pìr and 'Ālim Afzal Qadri: Portrait of a Moral Entrepreneur of Mobilisations}

Pir Afzal Qadri (Figure 14.1) was born 20 January 1953 in the city of Gujrat in Pakistani Punjab. He is the heir of a line of Barelwi Sufis and scholars and has become a "social movement entrepreneur", ${ }^{40}$ who has mobilised people for different causes revolving around the Prophet Muhammad. He is indeed a professional activist, with an important political and associational past and present,

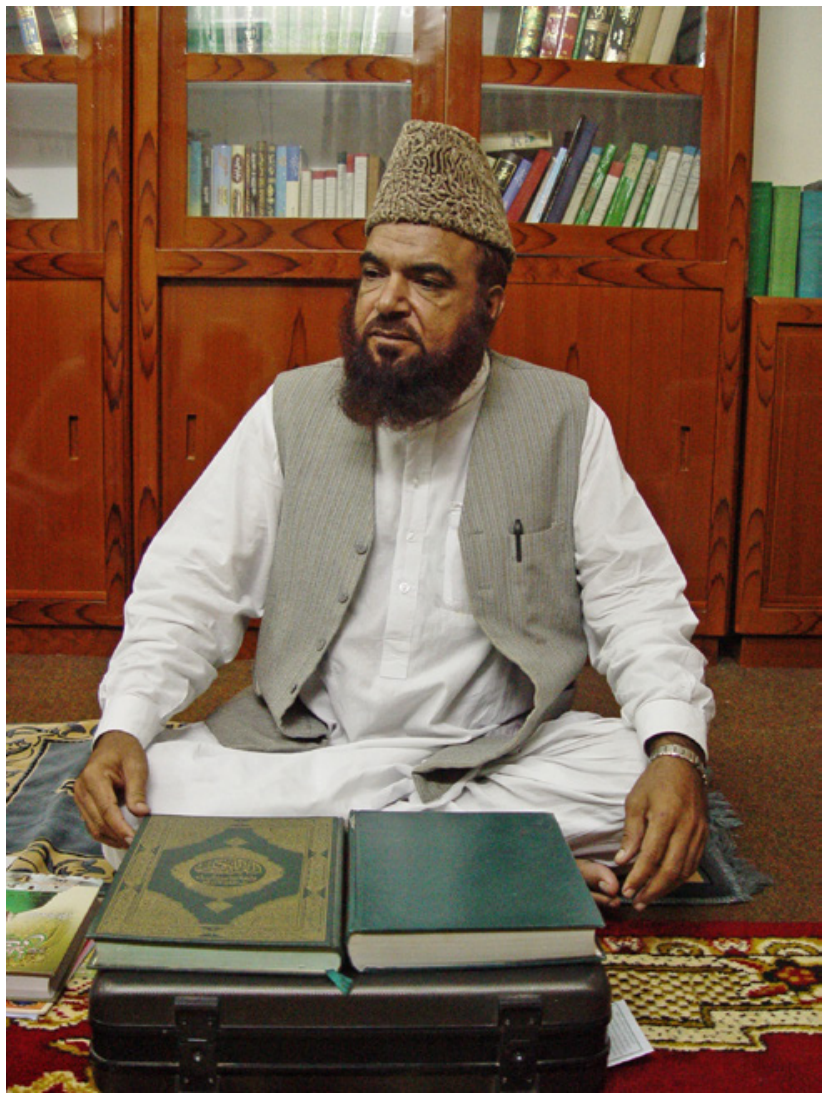

FIGURE 14.1 Pir Afzal Qadri, Mararian Sharif, May 2008

40 This notion was introduced by the theoreticians of the school of resources mobilisation John McCarthy and Mayer Zald. They argued that social movements are increasingly professionalised, and characterised by full-time leadership. Grievances do play an important role in social movements, but more important are the entrepreneurial leaders who take the initiative to organise them. See Staggenborg, "Entrepreneurs, Movements". 
who commands important political and religious resources. He is also a "moral entrepreneur" in the sense defined by Howard Becker, that is, an entrepreneur who either "creates norms" or "makes them implemented". The first type is the "crusader for the reform of mores" who thinks he has a "sacred mission" and is often "imbued with his own virtue". He is also focused on the "content of laws". ${ }^{41}$ In our case, it is the blasphemy law that is at stake. As we will see, the pir and his coreligionists do not want new laws to be passed, but the existing ones to be fully respected. The pir also enjoys a charismatic authority.

Generally speaking, Barelwi activists venerate their leaders who embody the group's ideals. They inspire love and respect, are a catalyst for commitment, and facilitate the identification of militants with their cause. ${ }^{42}$ Shaped on the model of the brotherhood, each of the Barelwi organisations displays a collective identity that can be encapsulated as an all-exclusive tie of loyalty and an allegiance towards a single authority on whom positive emotions converge. These charismatic leaders act as intermediaries with the Prophet whom they imitate and with whom they identify. Muhammad is the model of human perfection and embodies the ideal of the Sufi shaykh. The men who have reached spiritual perfection after him have been perceived by their fellow Muslims as role models and exemplars of absolute piety. ${ }^{43}$ That is very much the case with the most prominent Barelwi leaders who are considered as living saints and as living heirs of the Prophet by their followers. They are believed to have the ability to perform miracles (karāmāt). They are perceived by their community of devotees as saviours and heroes. And many of them have tried to preach through their publications. Thus, they are also scholarly saints. Esoteric knowledge and exoteric expertise are often associated in the formula of these leaders' authority. The friends of God (awliya allāh) are supposed to combine piety, exemplarity, and authority (as the word wilaya suggests with its connotations of power and patronage).$^{44}$

As indicated in his hagiography, Afzal Qadri legitimises his actions by claiming his privileged link with the Prophet Muhammad. During a Hajj he undertook in 1423 of the Islamic calendar (2002), he visited Medina where he had a spiritual vision of Muhammad who gave him good news: his Sufi lodge (khanqah) in Mararian Sharif, Gujrat, is nothing less than a link with Medina. ${ }^{45}$ It is also the headquarters of the organisation he founded in 1998, Almi Tanzeem

\footnotetext{
41 Becker, Outsiders, $171 \mathrm{ff}$.

42 Philippon, "Le charisme comme ressource émotionnelle du mouvement social".

43 Matringe, "Pakistan", 168.

44 Rozenhal, Islamic Sufism Unbound, 43.

45 Hagiography of the pir distributed by the ATAS.
} 
Ahl-e Sunnat (ATAS). The aims of the ATAS are to call people to Islam and teach them the path of the Prophet in the Barelwi tradition. But it is also a very sectarian and politicised protest group: Afzal Qadri thinks the secret services (ISI) have beefed up the "Wahhābīs" and weakened the Ahl-e Sunnat. ${ }^{46}$ In the eyes of the Barelwis, the Deobandis and Ahl-e Hadith are not real Sunnīs and their spread and influence must be stopped. But the Muslim umma also needs to be defended from "Jewish, Christians and other infidels". ${ }^{47}$ The scholar Arif Jamal called the ATAS a very small yet important Barelwi organisation. ${ }^{48}$ There are not many members in Pakistan (a few thousands), but the ATAS is supposedly present in thirty-six countries. However, its protests are led in a strategic way according to what Donatella della Porta and Mario Diani call the "logics of number", 49 trying to give an impression of numerical strength by multiplying marches, demonstrations, petitions, and so forth. The ATAS was almost banned in 2003 because of its sectarian and protest activities. For Afzal Qadri, the Musharraf regime wanted to fulfil the US agenda and turn Pakistan into a secular state. He even issued a fatwa against the then president, which led him to prison: "Any Muslim helping non-Muslims during the war between Muslims and non-Muslims is a kafir (infidel) and deserves to die." ${ }^{50} \mathrm{He}$ suggested the army should change his chief and find a new general who would also be a "real Muslim".

Prior to founding the ATAS, the pir was involved for twenty years in the main religious organisation of the JUP, Jama'at Ahl-e Sunnat Pakistan (JASP). He first became president of the Punjab province and was then elected secretary general in 1994. Besides his functions within the JASP, Afzal Qadri is also the heir (sajjada nashin) of a branch of the Qādirī order. He claims a direct descent from Hazrat Ali, even though he belongs to a Punjabi caste, the Khokar. He succeeded his father, Pir Mohammad Aslam, when the latter passed away in 2004. The brotherhood's headquarters are also a centre of Islamic teaching founded in 1905 by the pir's grandfather, Khwaja Mohammad Naek Alam Qadri. He is presented in the pir's hagiography as a "famous fakir" who had studied in Arabia and taught hadīths. He also performed miracles (sahib-e karamat), was a perfect saint (wali-e kamil) and a lover of the Prophet (ashiq-e rasul). He was the one to lay the first stone of the Jamia Qadiriyya at the beginning of the twentieth century where he built a mosque and a madrasa (Figure 14.2).

\footnotetext{
46 Interview with Pir Afzal Qadri, Pindi, May 2008.

47 Interview with Pir Afzal Qadri, Pindi, May 2008.

48 Interview with Arif Jamal, Lahore, April 2007.

49 Della Porta and Diani, Social Movements, 174.

$5^{\circ}$ Brochure of the ATAS. See also Jamal, "Politics of Fatwas".
} 


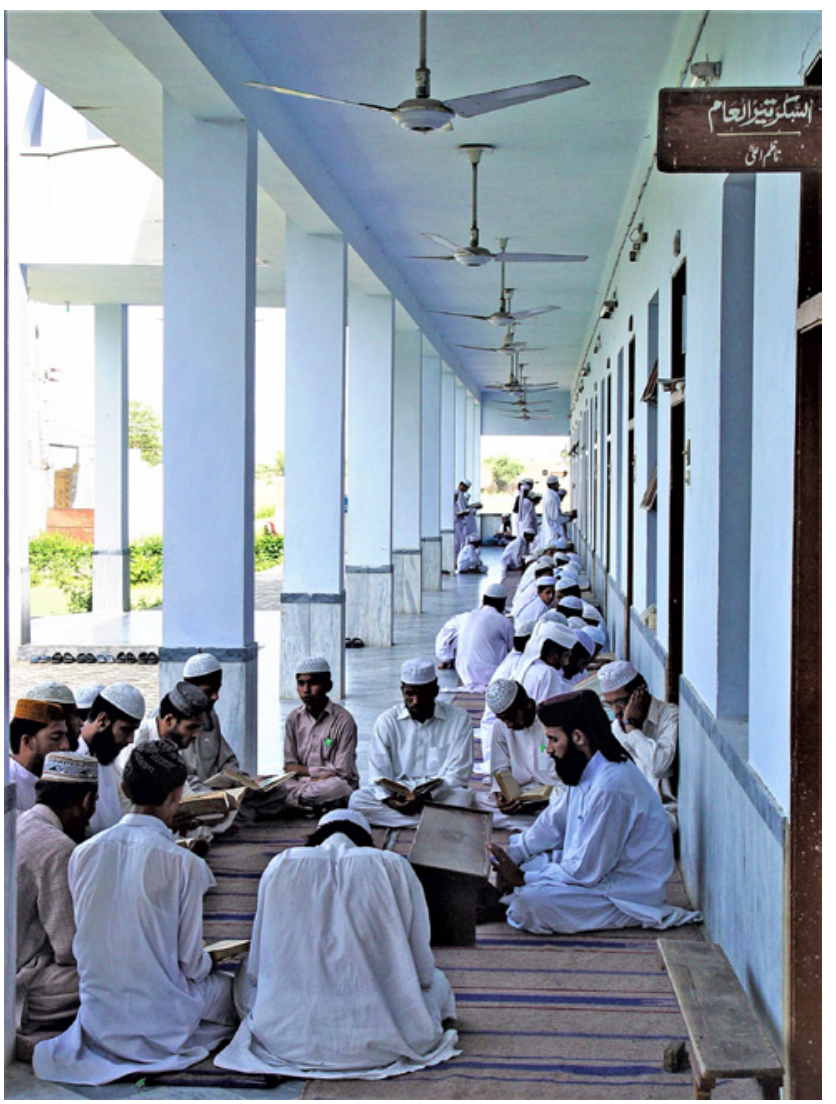

FIGURE 14.2 Madrasa for boys, Mararian Sharif, May 2008

After Khwaja Mohammad's death, his son and successor, Afzal Qadri's father, built another building devoted to Islamic education. Both an 'álim and a khalifa of his own father, he also received the khilafat from three Gaylānī pìrs from Baghdad. Twelve years before passing away, he transferred to Afzal Qadri the responsibility of taking care of his disciples. When I visited the centre in Mararian Sharif in May 2008, 700 girls and boys were being fed for free at the centre.

The girls' madrasa (Figure 14.3), Shari'at Girls College, managed by Afzal Qadri's sister, teaches the nizam-e mustafa to girls who are then encouraged to open their own madrasa for girls. Besides the girls' and boys' madrasas, the centre comprises a mosque and a shrine with the graves of Afzal Qadri's father and grandfather (Figure 14.4).

According to his hagiography, Afzal Qadri received religious education from different schools and scholars, including his own father and grandfather, and 


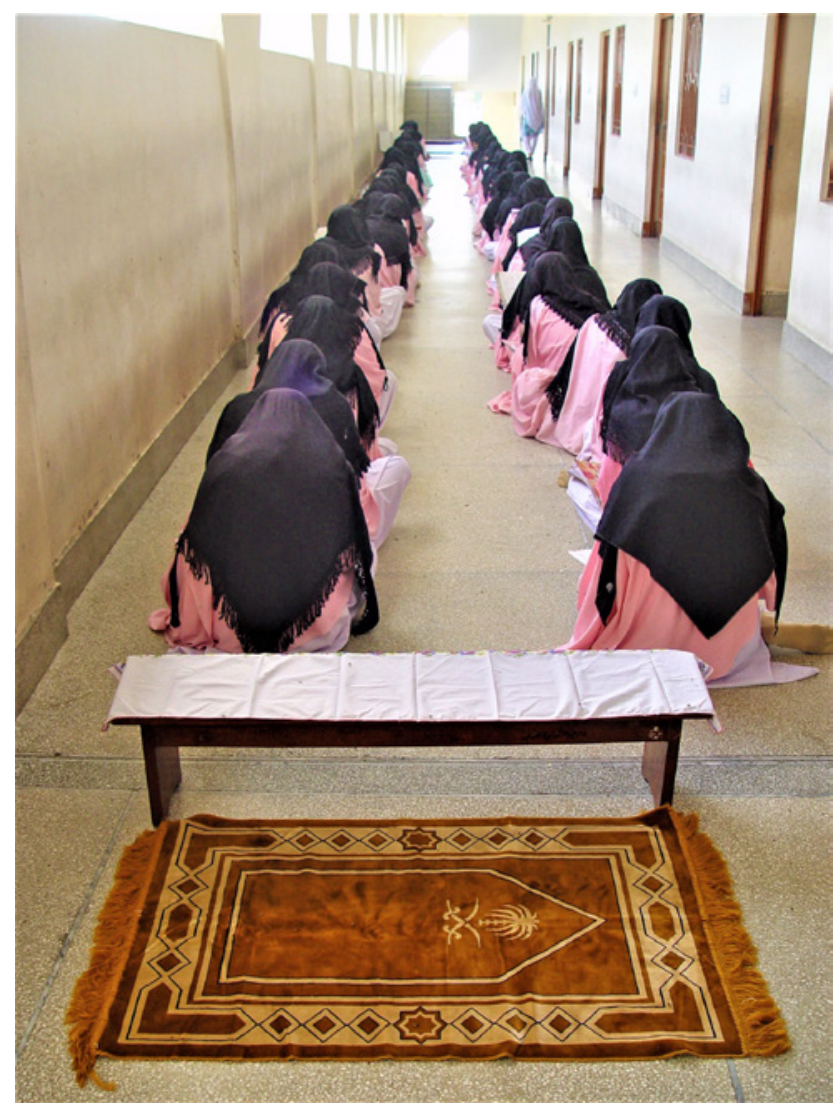

FIGURE 14.3 Madrasa for girls, Mararian Sharif, May 2008

started making his first sermons at the age of ten or eleven. Since 1992, he has been in charge of the Friday sermon (khatib) at the mosque of Mararian Sharif. He is known for his debates with "the Wahhābī enemies" but also for his spiritual powers. Numerous miracles are attributed to him, notably through dreams, as is so typical in the Barelwi tradition. One such miracle, involving the Prophet, goes as follows: the khatib of a nearby mosque in Faizabad, Khwaja Shakir Ahmed Owaisi, fell asleep while Afzal Qadri was giving a conference on the seal of prophecy. The khatib did not know such a conference was happening but he saw the Prophet in his dream, surrounded by a big escort. He asked the Prophet where he was going. The Prophet replied: “Don't you know Pir Afzal Qadri is making a conference on khatam-e nabuwwat? That is where I am going." ${ }^{1}$ As a matter of fact, khatam-e nabuwwat, the seal of the prophecy,

$5^{1} \quad$ Story narrated in the hagiography of the pir. 


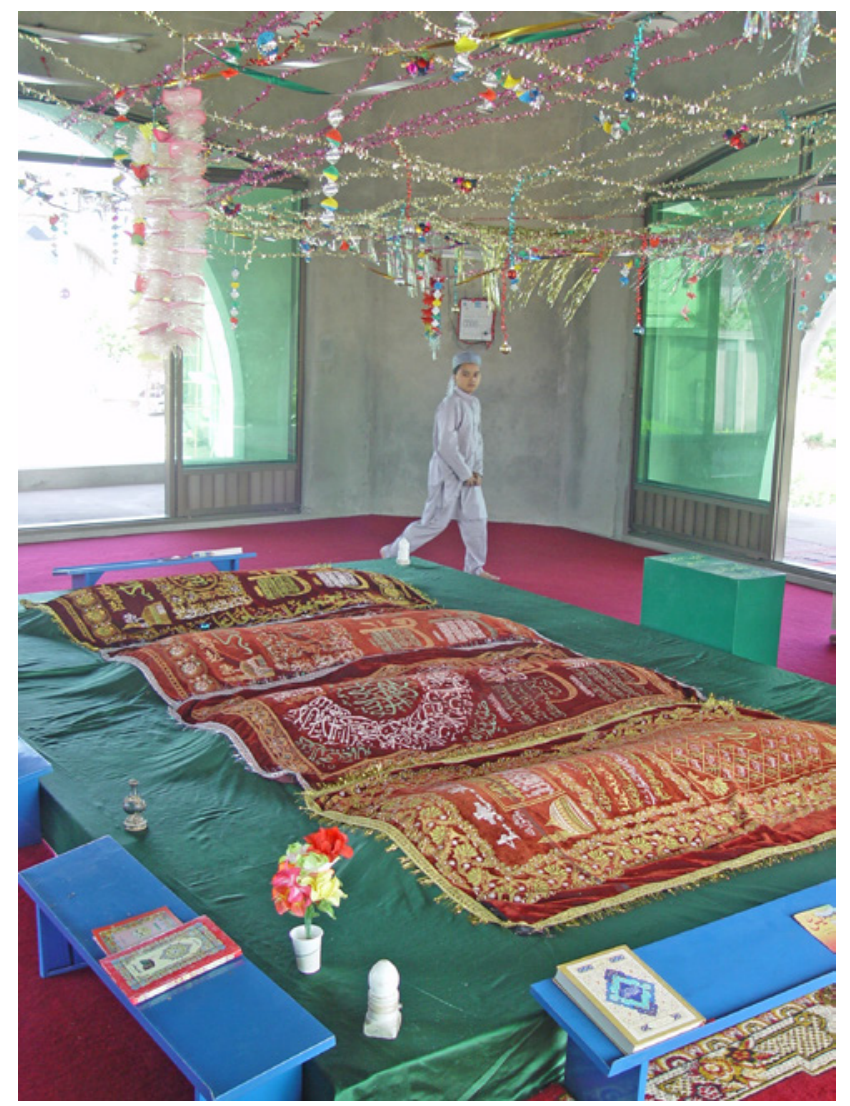

FIGURE 14.4 The graves of Pir Afzal Qadri's father and grandfather, Mararian Sharif, May 2008

is one of the many causes the pir has fought for throughout his career. His modes of action mainly include demonstrations, petitions, sit-ins, marches, and fatwas.

According to Afzal Qadri, heresy is a crime punishable by death. In 199o, the pir started mobilising against the Ahmadīs, by distributing sectarian literature and organising conferences. He claims to have been an inspirational force that led to the conversion of Ahmadīs and the transformation of Ahmadī mosques into "Muslim" ones. He has also mobilised in favour of the nizam-e mustafa. According to him, Pakistan was created for Muslims and Islam has to be implemented in both private and public life. Nizam-e mustafa is perceived as a complete code of life going beyond religion and comprising two main things: the relation with God (private rights) and social relations (public 
rights). "Mention any sphere of life and nizam-e mustafa has the answer."52 The spirit of the system is to serve humanity and live for others as the Prophet and Sufi saints did. The method advocated by the pir is to first implement it on oneself, before gradually Islamising the whole of society. Under Musharraf, on 19 November 1999, the pir organised a convention on the topic in Islamabad. He protested eighteen days in front of the military headquarters in Pindi to impose the system of the Prophet and numerous activists handed themselves to the law enforcement agencies..$^{53}$

Afzal Qadri also brought to the fore another issue: that of the destruction of the shrine of the Prophet's mother in a hill between Medina and Mecca. Barelwis have great respect for her and consider her grave as an important site of pilgrimage where the Prophet used to go and pray. But according to Wahhābì doctrine, the practice of tomb visitation (ziy āra) is an act of idolatry (shirk). The "Nejdis"54 destroyed the grave in March 1999. The pir launched a protest movement against the Saudi government for the grave to be rebuilt. On 14 April 1999, a demonstration of the ATAS comprising thousands of Barelwi demonstrators from different groups (ATAS, JASP, JUP, and others) as well as students from madrasas ${ }^{55}$ was organised in front of the Saudi embassy in Islamabad. A petition was handed, demanding the reconstruction of the grave. The demonstrators threatened to kill Saudi citizens in order to retaliate against the demolition. ${ }^{56}$ The demonstrators also accused the Saudi government not to be Muslim, or even to be "worse than the Jews". ${ }^{57}$ Letters were sent to ambassadors of Islamic countries to make them aware of the issue. The then prime minister, Nawaz Sharif, was also called to intervene and hundreds of Barelwi 'ulama $\bar{a}$ ' surrendered themselves to the law enforcement agencies in front of the parliament. The crisis lasted twenty days. Afzal Qadri was finally imprisoned in Pindi in May. According to Arif Jamal, this demonstration in front of the Saudi embassy has become an important step in the "politics of the Ahl-e Sunnat",58 notably because it was the first time that the Pakistani army was accused of being a "sacred cow", and of supporting the Jihādī groups in Kashmir instead of handling jihād itself. ${ }^{59}$

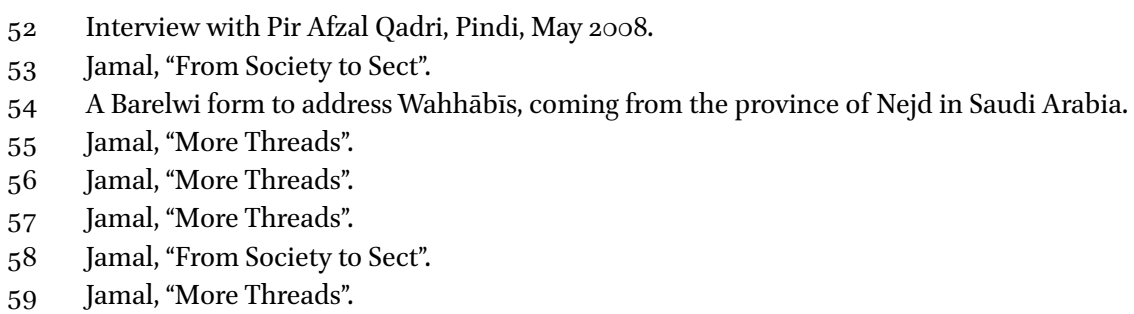


The pir has also consistently fought against any change in the blasphemy law positing that anyone insulting the Prophet deserves to die. In July 1994, under the Bhutto government, the law minister Iqbal Haider announced the amendment of the law. The pir then organised a strike in Gujrat and even issued a fatwa against the minister, stating he deserved the death penalty. Afzal Qadri was then imprisoned for three months. In April 2000, Musharraf also tried to amend the article. The ATAS then organised a massive demonstration in Lahore and clashed with the police. Almost 300 Barelwi pirs and 'ulama $\bar{a}^{3}$ were imprisoned. After the Danish cartoons' publications in February 2006, the ATAS organised a new demonstration in a train from Lahore to Pindi but the police arrested 150 activists, including the pir. They were chanting slogans against the government and demanded Musharraf's resignation for his inability to deal with this issue at an international level. ${ }^{60}$ Thus, Afzal Qadri is arguably one of the most experienced Barelwi mobilisers on the blasphemy issue. He has eventually joined the Tehreek-e Labbaik Pakistan (TLP) as its patronin-chief and has been fighting alongside its leader, Khadim Hussain Rizvi, to mobilise people.

\subsection{The Tehreek-e Labbaik and the "Moral Crusade"61 against Blasphemy}

The existence of the blasphemy laws in Pakistan is an important institutional setting to take into account. But the laws alone do not explain why the blasphemy issue has triggered such outrage over the past ten years. As we have seen, mobilisations to protect the honour of the Prophet and to fight against any amendments to the blasphemy laws are not new. Barelwi groups, amongst others, have consistently worked on making people aware of these issues. The existence and availability of moral entrepreneurs of mobilisations are another important factor to take into account in explaining the recent success of the mobilisations about blasphemy. Other structural factors are also to be envisaged: the "war on terror" introduced a new "structure of political opportunities", that is to say, resources, institutional configurations, and public policies that have facilitated the development of protest movements. ${ }^{62}$ New structural constraints and openings determined the course and the newfound success of the Barelwi mobilisations. First, the war on terror heightened the fears in

\footnotetext{
6o Daily Times, “Train March' against Caricature Foiled".

61 Becker, Outsiders, 176.

62 Kitschelt, "Political Opportunities", 58.
} 
Pakistan of a secularisation of the country under the influence of the US. The Islamists' hope of implementing the sharía being constantly frustrated, the blasphemy issue has come to condense all the tensions of Pakistani society. ${ }^{63}$ It has come to epitomise the endangered Islamic identity of the country. The war on terror also empowered Barelwis and re-legitimised them on the public sphere. Sectarianism between Sunnīs has thus grown increasingly violent. ${ }^{64}$ The Taliban of Pakistan are rooted in the Deobandi movement and promote a version of Islam that can become extremely hostile to the Barelwis. Since 2005, the Sufi shrines have been more specifically targeted by anti-Sufi militants, and such has been the case of Barelwi scholars. The intensification of violence can be partly explained by the fact that the Musharraf regime (1999-2008) has used Sufism to craft an official good version of Islam. This religious policy coincided with (or was an actual answer to) the active efforts from the part of US policymakers to construct a proper "moderate Islam". Sufism was erected, or even reified, as an "Islam of peace and love", and presented as an integral part of President General Pervez Musharraf's "enlightened moderation" and of the "soft face of Pakistan". This "strategic use of official religious discourse" indeed had fall-outs on the political opportunities structure and the complex processes of identity politics in Pakistan. ${ }^{65}$ The Barelwis, who have been identified as "good Sufis", have mobilised at the call of the government from 2009 onwards to "save the soul of Pakistan" against creeping "Talibanisation". After being marginalised for decades, these Barelwi groups sided with the powers that be in quest of material, symbolic, and political resources. The "Salafi" or "Wahhābī" trend being identified with the "bad Islam" to be combated worldwide, Barelwi actors emphasised publicly their identity of "good Sufi Muslims". They strongly reinforced the anti-Wahhābī narrative and gave more credit to the religious prism of understanding radicalisation or terrorism, emphasising theological factors whereas profane ones might actually be at stake. Many conferences aiming both at denouncing the "Talibanisation" and at reasserting the role of Sufis in the promotion of an Islam of "peace, love, and tolerance" in contemporary Pakistan have thus been organised. Barelwis became the beneficiaries of state patronage after a marginalisation that had lasted for decades. That change in old patterns intensified sectarianism and radicalised religious identities even more. ${ }^{66}$ Each religious movement competes with the other to represent religious values but also to vociferously organise its public defence.

63 Boivin, Le Pakistan et l'islam, 63.

64 Philippon, "Sunnis against Sunnis".

65 Sheline, "Branding Islam".

66 Philippon, "Positive Branding' and 'Soft Power". 
It is as much about piety and religion as about politics. Being entitled to represent the "good Sufi Islam" in Pakistan, the Barelwis mobilised even more stridently as "true lovers of the Prophet" at the risk of blurring the convenient good Muslim/bad Muslim dichotomy. That is notably the case after the murder by a young Barelwi militant of the governor of Punjab Salman Taseer. That incident appears in hindsight as a watershed in the "politics of blasphemy". Thus, the empowerment and public legitimisation of Sufi actors in a heightened sectarian environment might have paradoxically encouraged the radicalisation of some of them.

Indeed, it is a member of the Barelwi sectarian group Sunnī Tehreek who killed Taseer in January 2011. Taseer wanted to amend the blasphemy laws and publicly supported a young Christian mother accused of blasphemy in 2009 and sentenced to death, named Asia Bibi. He was also accused of committing himself blasphemy, notably by calling the blasphemy law a "black law". Taseer's killer and bodyguard, Mumtaz Qadri, instantly shot to fame after the murder. He became a hero and was glorified by large segments of the population and by members of corporations like lawyers. Some of them welcomed Mumtaz Qadri in the tribunal with rose petals and fought to have the honour to defend him in court. This appeared to many observers as a clear sign that the current radicalisation of Pakistani society was not only to be blamed on the Taliban, but paradoxically also on what some might perhaps call an overzealous interpretation of the veneration of Prophet Muhammad. During a conference in Lahore on "the preservation of the honour of the Prophetic message", Barelwi leaders warned the supporters of the defunct Taseer that a Mumtaz Qadri would be at every corner of the country to stop such displays of solidarity. "Don't associate Mumtaz with any terrorist group, they said. He is a true lover of the Holy Prophet (pbuh)." ${ }^{67}$ After his execution in February 2016, Mumtaz Qadri became a martyr before becoming a saint. A Sufi shrine has been erected by his family members above his tomb in Barakahu, near Islamabad, which is gradually becoming the locus of a pilgrimage (Figures 14.5 and 14.6). ${ }^{68}$

But Mumtaz Qadri has also inspired some of his coreligionists, such as Khadim Hussain Rizvi, the leader of the TLP. A traditional 'âlim (he is a hafiz-ul Quran and a shaykh-ul hadith), Rizvi has come to be known in religious circle as "the blasphemy activist".69 Until 2011, he was working for the Punjabi Ministry of Religious Affairs by delivering the Friday sermons in a mosque of the old city of Lahore, close to the big Sufi shrine of Data Sahib.

67 Tanveer, "Taseer Murder".

68 Observation of the author.

69 Kalbe, "Who Is Khadim Hussain Rizvi?" 


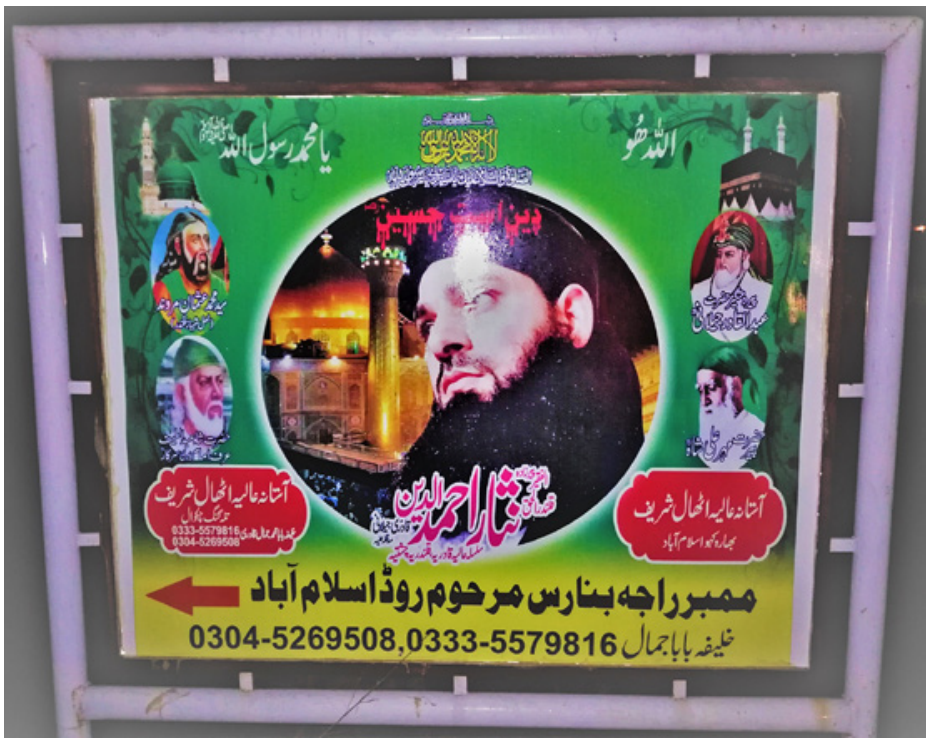

FIGURE 14.5 Signpost leading to the shrine of Mumtaz Qadri, represented with four Sufi saints, Barakahu, December 2017

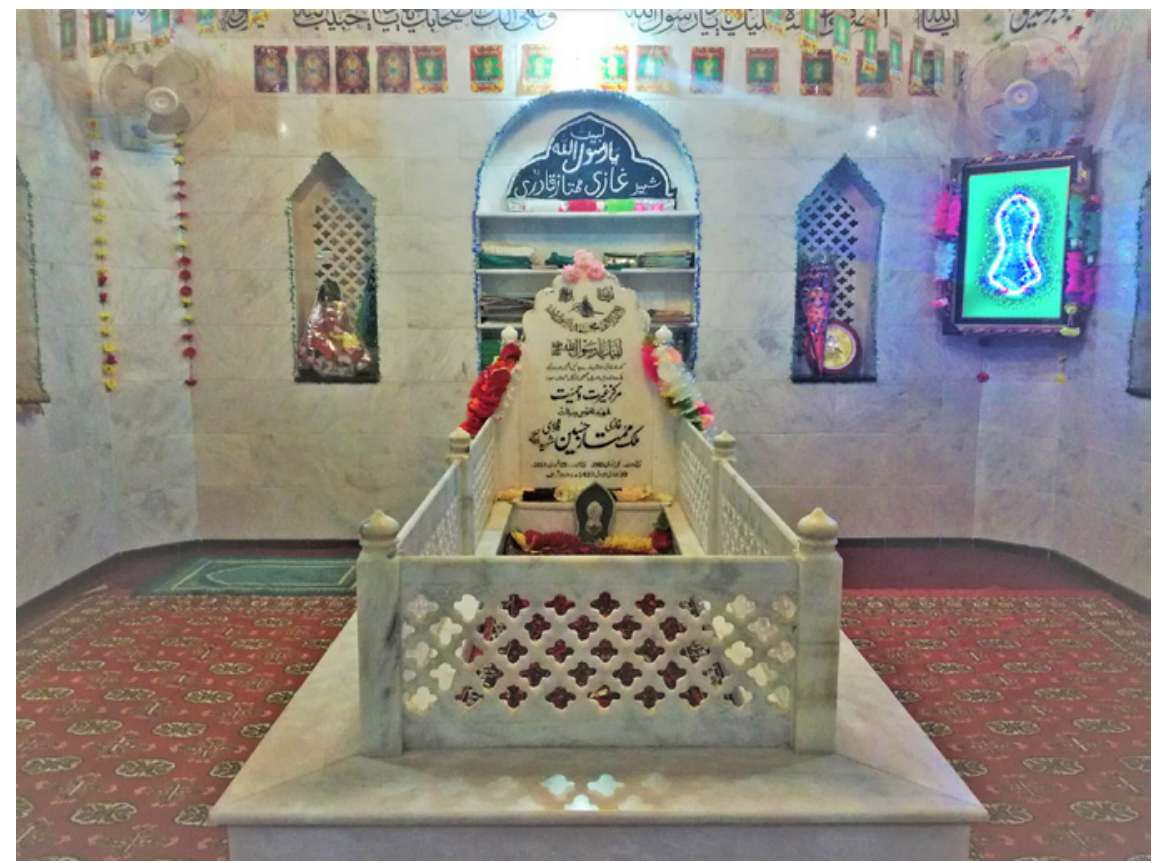

FIGURE 14.6 Shrine of Mumtaz Qadri, Barakahu, December 2017 
After Taseer's assassination, he publicly supported Mumtaz Qadri, which led him to prison. He was suspended from his job at the ministry, "started organising support for section $295 \mathrm{C}$ of the Pakistan Penal Code ... and travelled the length and breadth of the country for the cause". ${ }^{70} \mathrm{He}$ announced the foundation of the Tehreek-e Labbaik Ya Rasool Allah (TLY, later renamed as Tehreek-e Labbaik Pakistan, TLP) in August 2015, during a Barelwi gathering in the city of Karachi. ${ }^{71} \mathrm{He}$ is as famous for his use of Muhammad Iqbal's poetry as he is for his crude language. And he justifies his vulgarity, violence, and politics by his love for the Prophet. ${ }^{72}$ After Mumtaz Qadri's execution in February 2016, he decided to get into electoral politics. He supported one of his disciples, who was an independent candidate in the important by-elections held in Lahore in September 2017, in the fiefdom of the party then in power, the Pakistan Muslim League Noon (PMLN). The former prime minister Nawaz Sharif had just been dismissed following the Panama Papers scandal. The campaign of the TLP candidate was only focused on the image of Mumtaz Qadri, who was shown victorious on posters after Taseer's assassination. The results of the polls amazed most observers. The candidate obtained more votes than his rivals from mainstream political parties, whether secular like the PPP or religious like the JI. The very same dynamics were to be observed in the by-elections in Peshawar on 26 October, where a TLP candidate was fielded. A few weeks later, in November, Rizvi launched a three-week sit-in (6-27 November) in the capital, Islamabad, and within a short span of time he became a "formidable political leader". ${ }^{73} \mathrm{~A}$ few thousand members of the TLP camped just outside Islamabad at Faizabad Interchange. Their aim was to protest against the modification of the clause on the finality of prophecy in the bill on electoral reforms adopted in October 2017. At first sight, no major issue was involved: the members of parliament had simply modified the oath that candidates for elections have to make and where they have to declare that Muhammad is the last prophet. The expression "I solemnly swear" had been transformed into "I solemnly affirm".74 The modification was deleted when the "mistake" was noticed. But the protestors did not care: they wanted the people responsible for the amendment to be punished. In their eyes, the incident appeared to be an insult to the Prophet and therefore a blasphemy case. A policeman was killed, and others wounded in the confrontations with armed Barelwi men called by Khaled Ahmed, one of

$70 \quad$ Kalbe, "Who Is Khadim Hussain Rizvi?"

71 Shahid, "If I Curse in Anger, It Is Justified".

72 Shahid, "If I Curse in Anger, It Is Justified".

73 Kalbe, "Who Is Khadim Hussain Rizvi?"

74 Ahmed, "State's Surrender", 26. 
the most respected political analysts of Pakistan, a "mostly unemployed underclass of bearded men who clearly enjoyed the outing".75

The mobilisation quickly attracted the attention of the media. Worried articles started to appear in most English newspapers. The author and prominent columnist Zahid Hussain deemed the TLP to be a new phenomenon, more dangerous than other extremist groups in the country because of its "emotional appeal among the less educated populace. The filthy language used by these clerics and the open incitement to violence has made the lives of not only members of minority religious communities but also moderate Muslims more vulnerable to mob violence. ${ }^{76}$ An international relations professor from the University of Karachi, Moonis Ahmar, in a column in the Daily Times asked: "Where is the state?"77 He resented the incapacity of the government to implement the rule of law and its weakness in the face of a few thousand protestors. The reaction of the Minister of Interior Ahsan Iqbal, who had just recently survived an assassination attempt by a TLP member, was at first cautious: he deployed the police and then the Punjab Rangers without any success. ${ }^{78}$ The government then turned towards the military institution that chose to play the role of mediator by helping the TLP to be granted most of its demands. Numerous observers analysed the army's strategy as an attempt to destabilise the government of the Muslim League. In any case, the army's intervention legitimised the mobilisation. On 27 November, after the army distributed 1,Ooo-rupee bills to the protestors, TLP protestors ended up obtaining what they had asked for: a six-point agreement was notably signed by Pir Afzal Qadri, Khadim Hussain Rizvi, and the interior minister, amongst others, implying the immediate resignation of the law minister, Zahid Hamid. ${ }^{79}$ The protestors were assured that all those who were arrested during the sit-in would be released. The English media were unanimous in condemning the weakness of the government: the Dawn editorial of 28 November evoked a "capitulation". "General Capitulation" was also the title of Newsline magazine in December, ${ }^{80}$ and "State Surrender" was that of Newsweek. Khalid Ahmed eloquently wrote in his long Newsweek article that "the Pakistan that existed before November 27 is no more; Khadim Hussain Rizvi and his followers may well shape the identity of the one that emerges in the days and weeks to come." ${ }^{81}$

\footnotetext{
75 Ahmed, "State's Surrender", 25.

76 Hussain, "The Flames of Bigotry".

77 Ahmar, "Where Is the State?"

78 Rangers are paramilitary forces ensuring the domestic security of Pakistan.

79 Shahid, "General Capitulation".

$80 \quad$ Shahid, "General Capitulation".

81 Ahmed, "State's Surrender", 27.
} 
As these few opinions show, the liberal Westernised intelligentsia of Pakistan took stock of the spectacular and worrying way in which the stakes were being raised around the blasphemy issue. This issue is now being brandished as a tool of political legitimisation and as an instrument for the limitation of freedom of expression. But these reactions are not representative of public opinion. Indeed, blasphemy has over the years become a very dear cause to the heart of Pakistanis. TV channels in Urdu have attacked the government for its "crimes against the Prophet of Islam".82 In the political field, the leader of the Pakistan Tehreek-e Insaf and new prime minister since August 2018, Imran Khan, has lauded the military intervention and the success of the mobilisation by indicating that some members of the party were willing to participate. ${ }^{83}$ A serious poll conducted by Gallup Pakistan, the best poll institute of the country, in January 2018 reveals that public opinion is rather favourable to Khadim Hussain Rizvi. ${ }^{84}$ Forty-one per cent of the 1,646 people interviewed said their opinion of Rizvi was good or very good, 23 per cent bad or really bad, 28 per cent were indifferent, and 8 per cent did not know or did not answer.

In today's Pakistan, the popularity of movements against blasphemy has thus dramatically risen. As analysed by the anthropologist Paul Rollier,

this article of the Penal code has become for a large part of the Pakistani population a sort of a fetish, the ultimate symbolic and legal guarantee of the Islamic character of Pakistan.... The issue of blasphemy and the popular mobilisations against it have now clearly been co-opted and supported by the state. They have become the vehicles of a certain Pakistani nationalism, however exclusive it is. If the state does not harness these mobilisations, it is its own popular legitimacy that is threatened. So it is impossible for the government to change laws on the matter. ${ }^{85}$

Nothing better illustrates that analysis than the advertisement published in the daily newspaper The Nation on 7 January 2018. It portrayed the chief minister of Punjab, Shahbaz Sharif, in a position of prayer $\left(d u^{\prime} a\right)$, by the Dome of Medina, along with the title: "Eternal devotion for the holy Prophet (pbuh). Faith in finality of prophethood. To establish tolerant and harmonious society and revive the Sufi traditions. In the company of great spiritual leaders, famous

\footnotetext{
82 Ahmed, "State's Surrender", 26.

83 Ahmed, "State's Surrender", 26.

84 Gallup Pakistan, Accessed 26 September 2021, ... http://gallup.com.pk/wp-content/ uploads/2018/o1/Jan-8-1.pdf.

85 Rollier, "Sacrilège et politique religieuse au Pakistan".
} 
scholars and the custodians of prominent shrines," that is to say, the Barelwis. As Dale Eickelman and James Piscatori would say: "Rulers ... routinely invoke Islamic imagery and ideas to legitimize their rule and to defend themselves against Muslim critics." 86

\subsection{Conclusion}

The reassertion of the Barelwis in the political field appeared to many observers as a possible game changer in the July 2018 general elections. According to the researcher Amir Rana, director of the Pakistan Institute of Peace Studies: "The TLY has succeeded where many other Barelwi organisations had failed: it has been able to be considered as a major threat in the next general elections for the mainstream political parties, especially the PMLN." ${ }^{87}$ In today's Pakistan, the struggle against blasphemy has indeed become a valid manifesto for elections. As a matter of fact, the TLP successfully mobilised voters (2.2 million) and became the fifth-largest vote-getter in the 2018 general elections (and the third for the province of Punjab). This electoral empowerment of the Barelwis on the national political scene was based primarily on their agenda of protecting the Prophet's honour and the finality of his prophecy. For some observers, it is the first time in Pakistan's history that a two-and-a-half-year-old party has succeeded in mobilising such human resources in terms of candidates, both for the provincial and national assemblies' seats nationwide. ${ }^{88}$ As far as funding their campaign was concerned, TLP leaders managed to benefit from strong social and religious networks comprising thousands of mosques and shrines covering the whole Pakistani territory. These pre-existing networks of solidarity influenced the structure of the mobilisation that has succeeded in capturing them ${ }^{89}$ and also helped the party candidates legitimise their campaign in the eyes of the population. Besides that, TLP leaders have also succeeded in challenging the old doctrinal hegemony which the Deobandis/ Salafis have been enjoying since the 1980s. "In fact, their power goes beyond deciding who is and is not a good Muslim: they can simply decide who is not a Muslim and then hang the threat of death upon any head anytime."90 And their street power remains remarkable: the recent acquittal by the Supreme

\footnotetext{
86 Eickelman and Piscatori, Muslim Politics, 5.

87 Amir, "The Rise of Barelvis".

88 Hussain, "New Arrival", 7.

89 Oberschall, Social Conflict.

9o Hussain, "New Arrival", 7.
} 
Court of Asia Bibi led in November 2018 to the TLP bringing the country to a standstill through massive nationwide demonstrations. The party called for mutiny within the army, threatened to kill the judges, and pushed for Bibi to be hanged. The government met this new threat of the Suf Islamists with a massive countrywide crackdown on thousands of TLP workers and leaders. The latter have been booked under sedition and terrorism charges. The party appears to be much weaker now, even though both Pir Afzal Qadri and Khadim Hussain Rizvi were finally granted bail by the Lahore High Court in May 2019, a few days after Bibi left Pakistan for Canada. ${ }^{91}$

\section{Bibliography}

\section{Primary Sources}

Ahmed, M. M. Nida-e Ahl-e Sunnat, Lahore, Frontier Printing Press, July 1996.

Constitution of the JuP (Dastūr-e Jam'iyyat-e 'Ulama-e Pākistān), Central Secretariat of the JuP, n.d.

Constitution of the Islamic Republic of Pakistan (1973), "Chapter 5 - Interpretation", Accessed 26 September 2021, http://www.commonlii.org/pk/legis/const/1973/13 .html\#c5.

Gallup Pakistan, Accessed 26 September 2021, http://gallup.com.pk/wp-content/ uploads/2018/o1/Jan-8-1.pdf.

Nida-e Ahl-e Sunnat, Lahore, Frontier Printing Press, April 1995.

Nida-e Ahl-e Sunnat, Lahore, Tayyeb Iqbal Printing Press, February 2002.

Zadiri, A. R. Da'wat-e Inșāf [no longer available on the online library of the Sunnī Tehreek].

\section{Secondary Literature}

Ahmad, M. Jam'iyyat 'Ulama-i-Pakistan 1948-1979, Islamabad, National Institute of Historical and Cultural Research, 1993.

Ahmar, M. "Where Is the State?", Daily Times, 17 November 2017, https://dailytimes .com.pk/141077/where-is-the-state/.

Ahmed, K. "State's Surrender", Newsweek, 2-9 December 2017.

Amir, R. "The Rise of Barelvis", Dawn, 3 December 2017, www.dawn.com/news/ 1374276.

Becker, H. Outsiders: Etudes de sociologie de la deviance, Paris, Métailié, 1985.

Bernstein, M. "Celebration and Suppression: The Strategic Uses of Identity by the Lesbian and Gay Movement”, American Journal of Sociology 103/3 (1997), 531-65.

$91 \quad$ Haroon, “TLP’s Khadim Rizvi”. 
Blom, A. “The 2006 Anti-'Danish Cartoons' Riot in Lahore: Outrage and the Emotional Landscape of Pakistani Politics", South Asia Multidisciplinary Academic Journal 2 (2008), https://doi.org/10.400o/samaj.1652.

Boivin, M. Le Pakistan et l'Islam: Anthropologie d'une république islamique, Paris, Téraèdre, 2015.

Braud, P. L'émotion en politique, Paris, Presses de la Fondation Nationale des Sciences Politiques, 1996.

Cohen, A. P. The Symbolic Construction of Community, London and New York, Routledge, 2003 .

Daily Times, “'Train March' against Caricature Foiled”, 28 February 2006.

Daily Times, "Barelvi Scholars Want Death for Blasphemers", 13 March 2006.

Della Porta, D., and M. Diani. Social Movements: An Introduction, New York, Blackwell, 1999.

Eickelman, D., and J. Piscatori. Muslim Politics, Princeton, Princeton University Press, 1996.

Friedmann, Y. Prophecy Continuous: Aspects of Ahmadī Religious Thought and Its Medieval Background, new ed., New Delhi, Oxford University Press, 2003.

Haroon, M. "TLP's Khadim Rizvi, Pir Afzal get Bail”, The Express Tribune, 14 May 2019. Hervieu-Léger, D., and R. Azria, eds. Dictionnaire des faits religieux, Paris, PUF, 2010.

Hussain, S. T. "New Arrival", The News, 6 August 2018.

Hussain, Z. "The Flames of Bigotry", Dawn, 22 November 2017, www.dawn.com/ news/1372094.

Jamal, A. "More Threads in the Sectarian Cobweb", The News, 25 April 1999.

Jamal, A. "From Society to Sect", The News, 10 June 2001.

Jamal, A. "Politics of Fatwas", www.pakistanlink.com/Commentary/2004/Novi1/o5 .htm.

Kalbe, A. “Who Is Khadim Hussain Rizvi?", Dawn, 3 December 2017, www.dawn.com/ news/1374182.

Kitschelt, H. "Political Opportunities Structure and Political Protest: Anti-nuclear Movements in Four Democracies", British Journal of Political Science 16/1 (1986), $57-85$.

Laclau, E. On Populist Reason, London, Verso, 2005.

Malik, J. "The Luminous Nurani: Charisma and Political Mobilisation among the Barelwis of Pakistan", in P. Werbner, ed., Social Analysis 28 (1990), 37-5o.

Matringe, D. "Pakistan", in H. Chambert-Loir and C. Guillot, eds, Le culte des saints dans le monde musulman, Ecole française d'Extrême-Orient, Paris, 1995, 167-91.

Oberschall, A. Social Conflict and Social Movements, Englewood Cliffs, Prentice Hall, 1973.

Philippon, A. "Sunnis against Sunnis: The Politicization of Doctrinal Fractures in Pakistan", The Muslim World 100/1-2 (April 2011), 347-68. 
Philippon, A. "Le charisme comme ressource émotionnelle du mouvement social? Dispositifs de sensibilisation dans une néo-confrérie pakistanaise", Critique Internationale 1/66 (2015), 105-24.

Philippon, A. "'Positive Branding' and 'Soft Power': The Promotion of Sufism in the War on Terror", Brookings Institution, Washington, www.brookings.edu/blog/order -from-chaos/2018/12/13/positive-branding-and-soft-power-the-promotion-of -sufism-in-the-war-on-terror/.

Rollier, P. "Sacrilège et politique religieuse au Pakistan", Observatoire International du Religieux 13 (November 2017), 9-10.

Rozenhal, R. Islamic Sufism Unbound: Politics and Piety in Twenty-First Century Pakistan, New York, Palgrave, 2007.

Sanyal, U. Devotional Islam and Politics in British India: Ahmad Riza Khan Barelwi and His Movement (1870-1920), Delhi, Oxford University Press, 1996.

Sèze, R. "L’Ahmadiyya en France", Archives de sciences sociales des religions 171 (2015), https://doi.org/10.400o/assr.27152.

Shafqat, S. "From Official Islam to Islamism: The Rise of Dawat-ul-Irshad and Lashkar-e-Taiba”, in C. Jaffrelot, ed., Pakistan: Nationalism without a Nation?, Delhi/ London, Manohar/Zed Books, 2002, 131-47.

Shah, S. M. H. Religion and Politics in Pakistan (1972-88), Islamabad, National Institute of Pakistan Studies, 1996.

Shahid, K. K. "If I Curse in Anger, It Is Justified", The Friday Times, 1 December 2017.

Shahid, K. K. "General Capitulation", Newsline, December 2017, http://newsline magazine.com/magazine/general-capitulation/.

Sheline, A. "Branding Islam: The Strategic Use of Official Religious Discourse", paper at the workshop "The Middle East and the Geopolitics of Religious Soft Power", 18 April 2018, Brookings Institute, Washington.

Sherani, S. R. "Ulema and Pir in the Politics of Pakistan", in D. Hastings and P. Werbner, eds, Economy and Culture in Pakistan: Migrants and Cities in a Muslim Society, London, Macmillan, 1991, 26-46.

Staggenborg, S. “Entrepreneurs, Movements”, in D. Snow, D. Della Porta, B. Klandermans, and D. McAdam, eds, The Wiley-Blackwell Encyclopedia of Social and Political Movements, Hoboken, Wiley-Blackwell, 2013, 411-13.

Tanveer, R. "Taseer Murder: Sunni Ittehad Warns against Protests", Express Tribune, 10 January 2010, http://tribune.com.pk/stroy/101580/taseer-murder-sunni-ittehad -warns-against-protests/.

Tilly, C. La France conteste de r6oo à nos jours, Fayard, Paris, 1986.

Zaman, M. Q. Islam in Pakistan: A History, Princeton, Princeton University Press, 2018. 